\title{
Context-Based Meaningful Variation of Lexeme PRAVDA in Oldest Russian Code
}

\author{
O. A. Gorban' \\ Dept. of Russian Philology \\ Volgograd State University, VolSU \\ Volgograd, Russia \\ oa_gorban@volsu.ru
}

\author{
E. M. Sheptukhina \\ Dept. of Russian Philology \\ Volgograd State University, VolSU \\ Volgograd, Russia \\ em_sheptuhina@volsu.ru
}

\begin{abstract}
The title of the well-known old Russian code Russkaya Pravda is analysed and some factors that determine its understanding in Russian culture are discussed. The authors describe the etymology, meaning and derivational relations of the lexeme pravda and demonstrate that it syncretically denoted quality (justice, truth, innocence), action that is aimed at investigation of truth that is conducted in accordance with the truth of God and law that regulates the action. The place of Russkaya Pravda in the composition of Merilo Pravednoye $\left(14^{\text {th }}\right.$ century) and the Novgorod First Chronicle of Younger Recension is defined by means of semantic analysis of the titles of the texts under consideration and the titles of legal texts that they comprise, semantic analysis of the alternative titles of Russkaya Pravda (ustav, zakon) and comparative analysis of the meanings of the lexemes under study. As a result, semantic components of the lexemes ustav, zakon, sud, pravda that generate connotations, associations are defined and patterns of meaning in the title Russkayay Pravda are established.
\end{abstract}

Keywords-Russkaya Pravda; chronicle; Merilo Pravednoye; Old Russian text; semantic syncretism; lexical meaning.

\section{INTRODUCTION}

"Preže vsyakyya pravbdy dostoino estb o božii pravdě $g l<a g o l a>t i$ [Before every truth, God's truth is to be pronounced]" is a quotation from the Old Slavic Code Zakon sudnyy lyudem, which is included into the $14^{\text {th }}$ century Old Russian manuscript Merilo pravednoye [22, fol. 125 v.]. The quotation and the title of the manuscripts mentioned above comprise words that are semantically related to the title of the well-known Old Russian code Russkaya pravda and are considered vital for interpretation of the lexemes pravda, božiya pravda, zakon, sudnyi, merilo, pravednoye.

As a unique source of data on the history of Russian law, social and economic relations, Russkaya pravda has always attracted attention of many scholars who studied it from historical, legal and linguistic perspectives. The notion of pravda denotes one of the main concepts of Russian mentality that has not been fully researched in historical linguistics and this gap needs to be addressed. As Pravda Russkaya is part of numerous compilations of texts that vary in contents and size representing a great number of copies (over one hundred) of undefined date and origin, the purpose of the present study is to analyse the meaning of the lexeme pravda within the language system and in broad context of other texts. The study aims to establish patterns of meaning the lexeme pravda acquires in the context of the two Old Russian manuscripts Merilo pravednoye and Novgorod First Chronicle of Younger Recension. To achieve the purpose, methods of contextual and semantic analysis are employed and the etymology of the lexeme pravda is analysed.

\section{ORIGIN OF THE WORD PRAVLDA AND ITS MEANINGS IN THE OLD RUSSIAN LANGUAGE}

Due to its long history in the Russian language, the word pravda is deeply rooted in the mind of Russian language speakers.

According to etymological studies, the lexeme pravda and its cognates (pravyj - 'right', pravit' - 'to rule', pravilo 'rule', pryamoj - 'straight') derive from PIE *pro(interchange *-prō-, *-prǒ-, *-prē-) [1], meaning an action that is directed ahead through space, cf. Old Prussian pra'through, for', pra- 'pro-, cross-, trans-', Lithuanian pra'pro-, cross-, trans-', Old Indian pra-'in front of, over', Avestan and Old Persian fra-, Greek $\pi \rho o ́$ 'in front of', etc. [1].

The adjective *prō-v-ŏs > *pra- $v$ - $b$ that is formed with the $*$-v-/-vo- suffix attached to the root *pro- [2] was likely to mean some quality - 'directed ahead, straight'. The adjective is viewed as a base for the verb *praviti - 'to point ahead, to straighten' and, as many scholars believe, the noun pravbda (*prav-bd-a) $[2,3,4]$.

However, an alternative hypothesis, according to which the noun *pravbda derives from the verb *praviti, seems to be plausible. Speaking about deverbative nature of the noun*pravbda, the authors of the Etymology Dictionary of Slavic languages point out that in some historical dictionaries definitions of pravbda do not have the primary semantics of process, e.g. pravbda želězo - 'trial, investigation of the truth by red-hot iron ordeal', and the lexeme is placed in the category of justice [5]. The noun *pravi-dl-o > * pravi-l-o derives from the verb *praviti and is formed with the suffix that denotes 'instrument' $[3,4]$, i.e. 'a tool for straightening, pointing straight and ahead'. The adjective *prē-m-b is an $*_{-}$ $m$ - suffixed form of the root $*_{-}$prēe-, cf. Old Church Slavonic prěmo - 'straight, opposite', Old Russian pryamo - 'straight', pryamyi - 'straight' $[6,7]$.

As follows from the above, the root with interchanging vowels *-prō- / *-prē- that possessed the semantic component 
of space was used to generate semantically related lexemes. Those, despite having different paths in the Russian language evolution, held conceptual unity long enough.

It seems possible that in ancient times the root under invesigation represented the concept of something straight, directed ahead through space that in the mind of ancient people was probably associated with images of a road or a path. R. M. Tseytlin writes that the concept of a path as a paved, straight (shortest) road can be traced back to ancient times, which is displayed in the etymology of lexical subsets that denote 'way, road, path, passage' in a number of IndoEuropean languages that among others include Slavic ones [4]. It is indicative that the words with the root -prav-are used in combinations with the word potb in old Slavic texts [4]. These specific representations conveyed the idea of movement in the right direction along a straight (shortest) path that was perceived as an optimal and, consequently, an ideal (and the only) one. Deviating from a path was perceived as breach.

The idea of a specific straight path and related concepts (the notion of 'straight', 'straightness') was subject to figurative reconceptualization. R. M. Tseytlin presented a detailed analysis of the lexical sets with the root -prav- in Slavic languages [4], and reported that in old written texts these words were used in predominantly metaphorical contexts [4] and, consequently, they easily developed transferred meanings. For instance, the adjective pravyi had the following meanings: 'open-minded, sincere, free from deception'; 'right, fair'; 'true' among others. Later, the word pravyi lost the original meaning of 'straight'.

The authors believe that both the literal and transferred meanings of the lexeme pravyi share the semantic component 'conforming to a certain ideal', i.e. following a direction chosen, a course of events, a tradition, or a norm in all of its aspects. The verb praviti [7], the derivate of pravyi, also expressed the idea of achieving an ideal, e.g. 'to direct', i.e. to show the right way; 'to counsel', i.e. to ensure proper conduct, to teach life skills; 'to rule', i.e. to organize an activity in the optimal way; 'to correct', i.e. to bring in line with a norm or a model; 'to judge, try a case; to execute a judgment', i.e. to bring an unsettled situation back to conformity with legal norms.

The rule, indeed, was percieved as an instrument to achieve correction, counseling, conformity with the norms. Dictionaries of Old Russian Language enumerate the following meanings of the noun pravilo (rule): 'steeringwheel, rudder; tiller', 'gear for handling the sails, brace', 'construction instrument for vertical stonework and making right angle turns' among others; 'portable rudder; governance, power, supremacy'[8], 'established rule, canon' [7] among others.

Taking into consideration the deverbative origin of pravbda (*pravbda от *praviti) expressed in the Etymology Dictionary of Slavic languages, it is necessary to point out that the lexeme retains its primary semantic component of 'process': bringing something in conformity with the benchmark, norm, or example. By the time this word first appeared in written texts this semantic component had become rather vague in its most meanings, with the primary component now being 'conforming to an ideal', for instance when it means 'truth', i.e. the real state of affairs; 'justice', i.e. unprejudiced adherence to the truth; 'goodness', i.e. following the Christian commandments; 'innocence', i.e. conformity with the law, determined during court trial.

Nevertheless, the semantic component of process remains in the meaning of pravbda as 'court trial': ... a na pravdu ězdyatb oboi [9]. As a result of metonymic transfer, this meaning generated another meaning - 'rules of court' or 'law' ('justice is administered in accordance to the law'). It is obvious that this meanining is used in the title of the old Russian law manuscript - Russkaya Pravda - which represents the legal practice of East Slavs; scientists call this artifact a collection of criminal and criminal procedure law [10], code of justice (sudebnik), [11]; Sudebnikb is also the title of the two $15^{\text {th }}$ century copies of Russkaya Pravda [12].

The meaning of 'conforming to an ideal', regarded as a positive quality, contributed to the formation of axiological value of 'truth', as one of the first and foremost concepts of Old Russian mindset. This concept was thoroughly researched by V.V. Kolesov [13] in various perspectives. The scientist reviews the interrelation between the notions of truth (pravda and istina) both in Old Russian and in modern Russian language consciousness, meanwhile highlighting the syncretic semantics of the Old Russian word pravbda, in which the notions of 'truth' and 'justice' were not opposed but interwoven. V.V. Kolesov reports that the split of the Truth into truth and justice occurred as a result of historic development and orientation towards the new culture. The syncretic ambiguity of the Slavic root -prav- gradually diffirentiated as suffix-built words developed - one by one different co-meanings of this root [13]; the Slavic mindset the juxtaposition of Slavic and Christian views on 'truth' (pravda and istina, respectively) took a long time to adapt to the Slavic mindset and never reached completeness when it came to the interpretation of these dialectically developed relations. This process of ethic attraction and semantic repulsion is still ongoing [13].

Semantic syncretism, which is defined as semantic indivisibility of a lexical unit - a word (a word group), uneliminated, and sometimes ineliminable, indiscretion in word semantics, and diffusivity, indiscretion of lexical or categorical semantics [14], is associated with semantics of nouns that express either positive or negative evaluation [15]. Specialists note that this syncretism manifests itself in texts produced as in the speakers'mind these lexemes are associated with uncategorised representation of reality conceptualised by an extremely broad concept [14]; the specifics of ancient people's worldview, i.e. integrity and figurativeness, are reported in: $[16,17]$.

Although lexicographers present the semantic structure of the lexeme pravbda as a hierarchical set of meanings it is still characterised by semantic syncretism, as these meanings are diffusive and they do not always realise on a syntagmatic level, which is observed not only in Old Russian contexts, in which the lexeme pravbda is used, but also in scientific commentaries on semantic interelation (that is occasionally semantic opposition) between the concepts of pravda - istina 
- spravedlivost' and the meanings of lexical units that represent them.

The lexeme pravbda was often used in Old Slavic texts: there are over 100 occurrences of this word in late $10^{\text {th }}-$ early $11^{\text {th }}$ centuries Old Church Slavonic manuscripts [6] and over 1,000 occurrences in Old Russian collections [7]. Used in various contexts in the source texts that belong to different genres, the lexeme pravbda obtains subtle meaningful nuances and connotations that enrich the imagery and associations the word evokes in the mind of the reader. Likewise, meaningful semantic variation of the lexeme is observed in the title of the law manuscript Pravda Russkaya.

\section{RUSSKAYA PRAVDA AS AN OBJECT OF STUDY}

To date, three recensions of Russkaya Pravda are known, i.e. the Short Edition (Kratkaya), the Extensive Edition (Prostrannaya), and the Abridged Edition (Sokrashchyonnaya), whereas some scholars consider the Abridged Edition as a variation of the Extensive Edition in numerous copies. A. A. Zimin writes that all these documents are not separate titles but represent parts of text collection (usually chronicles or law compilations). This is why scientists do not analyze Pravda Russkaya separately but in relation to other text sources that are included in the manuscripts. It helps to date Russkaya Pravda (in all its forms), reveal reasons for its creation and establish its interrelation with other legal artifacts widely known in Rus' [18]. Although the scholar pointed out to researchers who focused on the history of Russian state and law, it should be mentioned that papers that deal with linguistic issues also employ a comparative approach. For instance, A. A. Gippius examined the morphological data of Russkaya Pravda and Voproshanie Kirika (The Questions of Kirik), which are parts of late $13^{\text {th }}$ century Novgorodskaya Kormchaya manuscript, and reported on the complex nature of interrelation between standard Old Russian and hybrid Old Church Slavonic in the historical context of the Russian literary language [19]. In an attempt to develop criteria that could be used to define the genre and stylistic features of the text, G. A. Nikolaev considered not only the presence of certain derivative forms but also the quantitative correlation between them in the first part of Russkaya Pravda (Sud Yaroslava Vladimiroviča - 'The judgement of Yaroslav Vladimirovich') and Zakon Sudnyj Lyudem, that are equal in size and similar in contents, both are included in the $14^{\text {th }}$ century Merilo Pravednoye [20].

Russkaya Pravda is considered not only as a source of historical and linguistic evidence but a text that despite its heterogeneity, unknown origin, and long period of existence (that accounted for diverse diachronic linguistic and denotative layerings), has certain features of a text, i.e. structure (division into articles) and a title. Besides, it is a part of compilations that also compose a text. Their micro- (an article or a chapter) and macrotextual (the whole collection) elements show peculiar realisation of such text categories as dividedness, cohesion, prospection, retrospection, completeness, and integrity among others [21]. Certain words, especially when they are placed in strong text positions, e.g. in the title, can obtain additional meanings that arise not only due to the influence of-immediate context but also broad context formed by the whole collection of texts. The authors consider that meaningful variations of the lexeme pravbda that is used in the title of the reviewed manuscript is worth being examined.

This article presents analysis of the two texts of Russkaya Pravda from manuscripts that include various contents and genres - the $14^{\text {th }}$ century Merilo Pravednoye and the $15^{\text {th }}$ century Novgorod First Chronicle of Younger Recension according to the Commission List.

\section{VARIATION IN THE MEANING OF THE TITLE RUSSKAYA PRAVDA FROM MERILO PRAVEDNOYE}

$14^{\text {th }}$ century Merilo Pravednoye is a compilation of texts that are related to church law and legal issues. The contents of the collection are expressed in its title, which is written under the headpiece with cinnabar ink following the established book-writing tradition: «Siya knigi mérilo pravednoye. izvěsb istinbnyi. světb umu. oko slovu. zercyalo svěsti. tmě světilo. slěpotě vožb. priputens umb. skrovens razumb. prikrutb pomyslb. pastyrb stadu. korablyu kormbnikb. volkomb lovecb. tatemb pesb. voronamb sokolb. netopyremb $s<o>$ lnce. oku kvasb. červems solb» [22, fol. 2]. The phrase mérilo pravednoye - 'right, correct scales', which metaphorically means 'benchmark; something that allows one to make a judgment about something by weighting, measuring; to estimate' [7, 8], remains the conventional title of the compilation. It is accompanied by the synonymous phrase izvěs things, benchmark' [7, 8], expressing the same meaning, and by a series of figurative epithets to describe the moral and spiritual mission of the book, which is to instantiate the idea of fair justice and a fair judge and as M.V. Karagodina points out to demonstrate that what all righteous judges have in common are wisdom and wish to live under the law of the Lord [11]. This idea threads throughout the book, ensuring its thematic unity as a text, and is clearly expressed in the foreword to the collection.

The construe of Merilo text is actualized in its formal structure that is formed by conceptual blocks. The collection consists of two parts: the first one includes homilies about unrighteous and righteous judges; the second one is divided into 30 chapters of legal works (Zakon sudnyj lyudem, Zakon gradskij, and Russkaya Pravda among others). The chapters in both parts have titles (the headlines are written with cinnabar ink and emphasized with special graphic symbols) and sometimes contain articles with headlines; the second part is preceded with the table of contents with numbered sections.

$14^{\text {th }}$ century Merilo Pravednoye comprises the Extensive edition of Russkaya Pravda, which is a copy of the so-called Sinodalno-Troitskaya group (the authors follow the classification of the copies of Pravda and the numbering of its articles according to [12]). Its components, namely the Yaroslav Vladimirovich's Justice and the Law of Vladimir Vsevolodovich, are included as two separate chapters, which is evident from the table of contents of the second part.

The word pravbda, placed in a strong position of the text, i.e. in the title, reflects the contents of the text (chapter) and forms meaningful relations with the words in the title and the 
text in other chapters as well as the title of the whole collection of texts on a conceptual level (see Table 1).

Russkaya Pravda in this copy, as well as in the majority of other copies, has an extended title, which is $\mathrm{Su}(d)$ yaroslavlb vo(lo)dimerič $[22$, fol. 332]; the first part of it being written in capitals with cinnabar ink, Pravda rusbskaya being written in usual ink only with the initial $P$ written in cinnabar. That is, it is designed to look like the beginning of an article and can be perceived as a subtitle (the second part's table of contents lists only sudb yaroslavlb).

The word pravda is interrelated with the word sudb, complementing, specifying or, most likely, repeating its meaning (the adjective rusbskaya is used for specification, the meaning of which should be examined separately). This micro text has only one occurrence of pravda - in article 21: iskavše li posluha ne nalězutb. a istbcya načnetb golovoyu klepati. to ti ims pravdu želězo [22, fol. 333 v.]. This noun means 'trial ordeal', implying the usage of red-hot iron to find out the truth during the trial [12]. This word occurrs twice in articles 56 and 85 from the Law of Prince Vladimir: Aže zakupъ běžits o(t) gospody. to obelb idetb li iskatb kunъ. a yavleno hoditb. ili ko knyazyu ili $k b$ sudiyams. béžitb obidy delya svoyego $g<o>s<$ podi $>$ na. to pro to ne robyatb yego. no dati yemu pravdu [22, fol. 338 v.]; Ty tyažě vsě sudyatb posluhi svobodnymi. budetb li posluhb holopъ. to holopu na pravdu ne vylaziti [22, fol. 340]. In both contexts pravda means 'judgment, trial'. As can be seen from the above, in all the mentioned articles this noun bears the meaning of process, which reflects its deverbative origin.

The words $s u d b$ and ustavb within the frames of Russkaya Pravda itself (in the Laws of both Yaroslav and Vladimir) are used with performative verbs suditi and ustaviti, thus retaining their meaning of action or process: $s u(d)$ yaroslavlb ... a ino vse yako že yaroslavb sudilb. tako že $i \quad s<y>$ nove yego ustaviša [22, fol. 332]; ustavb vo(l)<o>dimě(r) vsevo $(l)<o>$ diča. Volodiměrb vsevolodičb. po $s<v y a>$ topolcé. sozva družinu svoyu ... i ustavili do tretbyago rěza [22, fol. 338]; Aže kto ubiyetb ženu. to těm že sudomb suditi. yako že $i$ тиža [22, fol. $340 \mathrm{v}$.].

TABLE I THE WORD PRAVLDA IN MERILO PRAVEDNOYE

\begin{tabular}{|c|c|c|c|}
\hline \multicolumn{4}{|c|}{ Merilo pravednoye, $14^{\text {th }}$ cent. $^{\text {a }}$} \\
\hline$I$ & & II & \\
\hline $\begin{array}{c}\text { SKAZANIE, } \\
\text { SLOVO, SUDb, } \\
\text { NAKAZANIE, } \\
\text { ZAKONb }\end{array}$ & $\begin{array}{l}\text { ZAKONb } \\
\text { ZAPOVĚDb } \\
\text { PRAVILO }\end{array}$ & $\begin{array}{l}\text { SUDb } \\
\text { 'rules of } \\
\text { court, law' }\end{array}$ & $\begin{array}{l}\text { USTAVb } \\
\text { 'law' }\end{array}$ \\
\hline $\begin{array}{c}\text { sudb, sudz božii, } \\
\text { suditi, zakonz, } \\
\text { pravbda 'truth, } \\
\text { justice', } \\
\text { pravbdbnyi 'just' }\end{array}$ & $\begin{array}{l}\text { nepravbda 'untruth, } \\
\text { nepravbdbnyi } \\
\text { 'untruthful, } \\
\text { dishonest', pravilo } \\
\text { 'rule', ispravlenie } \\
\text { 'correction', } \\
\text { pravoverrbny } \\
\text { 'orthodox, true } \\
\text { believer', } \\
\text { opravbdati 'acquit' }\end{array}$ & $\begin{array}{c}\text { Pravbda } \\
\text { rusbskaya } \\
\text { 'rules of } \\
\text { court, law' } \\
\text { suditi } \\
\text { ustaviti } \\
\text { pravbda } \\
\text { 'trial } \\
\text { ordeal' }\end{array}$ & $\begin{array}{l}\text { ustaviti } \\
\text { sudomb } \\
\text { suditi } \\
\text { pravbda } \\
\text { 'judgment, } \\
\text { trial' } \\
\text { pravbda } \\
\text { 'judgment, } \\
\text { trial' }\end{array}$ \\
\hline
\end{tabular}

${ }^{\text {a }}$ Tables I-III contain headings of the texts under scrutiny in capital letters, boldface is used for headings and subheadings of Russkaya Pravda, the lexemes under study are written in italics, definitions of meaning are given in quotes.
Placed in the title (or the subtitle), the word pravda interrelates with the titles of other micro texts in the second part of Merilo Pravednoye: $\mathbf{s u ( d )}$ yaroslavlb volodiméri( $\check{c})$ [22, fol. 332], ustavb vo(lo)dimé(r) vsevo(lo)diča [22, fol. 337], o vlasěhb ... pra(vilo) (fol. 344), zakona gorodbska(g)... [22, fol. 231], novaya zapově(d)... [22, fol. 198], zakonb sudnyi lyudems [22, fol. 125 v.] among others. Positioned in the same line with ustavb as 'charter, laws, a collection of laws or rules,' zakonb as 'law, judgment of the supreme authority', zapovědb as 'order, law, rule', and pravilo as 'a set rule, canon' or 'charter, code of conduct' [7], [8], [23] and as a result of metonymic transfer the words $s u d b$ and pravda are interpreted as nominations of courts acts and rules of trial procedure. The semantics of process in the title substantives is blurred while the semantic feature of objectness is brought into the foreground. Thus, the line of nouns is made up of appositional titles of functionally similar legislative acts, which ensures the unity of these documents as constituents of the second part of the collection.

The word pravbda and other derivatives with the root prav- (nepravbda, pravbdbnyi, nepravbdbnyi, opravbditi, pravilo, ispravlenbe, pravověrbnyi among others) can be found in non-title positions in other chapters of the second part of Merilo Pravednoye. They often occur in similar contexts with the derivatives formed from the roots -sud-and -zakon-, thus conceptualizing common semantic field, i.e. conducting a fair or an unfair trial, either according to the law or in breach of it. For instance: zlě mya osudiša. i ne po pravdu izveržens byhs [22, fol. 85]; ne syadeši s nepravednymi. byti neprav(d)enz svěditelb ne budeši ... i ubogago pomiluyeši. na sudě vnegda suditi yemu o(t) vsyakogo gl<agol>a o(t)stupiši nepravedna. nepovinbnago $i$ pravednago ne ubiyeši. $i$ ne opravdiši neč(s)tivago $i$ mbzdy ne vbzmeši. // mbzda bo oslěplyayetb oči vidyaščihb. $i$ pogublyayetb gl<agol>y pravedny. ne stvoriši nepravdy v sudě ... pravdoyu sudiši $[22$, fol. 118-118 v.]. In this fragment, the noun (ne)pravbda means '(in)justice', the adjective pravbdbnyi means 'honest, truthful (witness, speech)', 'not guilty', the verb opravbditi 'to declare not guilty'; sometimes these meanings are impossible to divide, e.g. c nepravednymi can be understood as 'with the dishonest', 'with the unjust', or, in brief - 'with the unrighteous' in every sense and manifestation of unrighteousness. Such contextual variations of the word pravda form conceptual background that facilitates its understanding and interpretations in the title pravbda rusbskaya. This is accompanied with variations in ethical and legal valuation of sud and pravda even when they are used as synonyms: sud can be both fair and unfair, while pravda is always a fair trial.

The word pravda is also related to the text titles from the first part of Merilo Pravednoye. These titles are names of the genres they represent (skazaniye, slovo, sudb, nakazaniye) or indirect descriptive nominations that provide insight into the contents of the text via the keywords suditi, sudb, pravbdbnyi, božii sudъ (o ispravlenbi suda, o vdovahı i o sirotahı da ne obidite $i h b$, etc.), titles of paradigmatic texts: the Bible, patristic literature, and other spiritual books (ot vtorago zakona, ot pčely among others), and authors of these texts, e.g. prophets, theologists (davida cbsarya, ioana zlatousta, etc.). 
Some of these titles form meaningful relations with the contents of the whole collection (sudb, pravda, zakonb), while others unfold the cultural importance and value of those terms: fair trial is included into the system of Christian values through references to the Bible and patristic literature.

The lexemes mérilo, pravbdbnyi, suditi, ustavb, sudb, pravbda and other semantically related words with sets of literal and transferred meanings form a single conceptual environment. The fragments in the book also rely on macro texts from the Bible and other spiritual and culturally important texts which together compose a megatext (the term by N. S. Kovalev [24]) of orthodox culture in ancient Rus', while the keywords they contain constitute the conceptual sphere of the Old Russian language.

The word pravbda that is used in the title of the legal artifact Pravbda rusbskaya, bearing the particular meaning 'law of court and trial', is semantically related to the titles of other chapters and the book Merilo pravednoye itself, thus, becoming semantically 'charged' by the contents of the whole collection. The semantics of the lexeme becomes broader than its separate meaning; it acquires the status of a concept and can be addressed from the perspective of Christian culture.

\section{VARIATION IN THE MEANING OF THE TITLE RUSSKAYA PRAVDA IN THE NOVGOROD FIRST CHRONICLE OF YOUNGER RECENSION}

In contrast to the earlier compilation, the Novgorod First Chronicle of Younger Recension, according to the Commission List, is a secular manuscript. Complex in composition, the text bears the essential features of a hybrid text type. It includes Russkaya Pravda as annual entry of the year 6524 (1016) and as part of other legal texts that follow the chronicle.

The annual entry quotes Russkaya Pravda in The Short Edition after the lines «a Yaroslavb ide $k$ z Kyevu ... i abie nača voi svoi dělitě ... a novgorodcomъ po 10 grivens vsěmъ, $i$ otpusti ihs vsěhs domovb, $i$ davъ ims pravdu, $i$ ustavb spisavb, tako rekši imb: "po se gramotě hodite, yakože spisahı vamъ, takože deržite». A se estb pravda ruskaa. <...>»[25, fol. 79 v.-80]. The title Pravda ruskaa (letters written with spacing in this chronicle) is written in cinnabar ink, followed by the text with no article division, although the introduction of the second part Pravda ustavlena Ruskoi zemli [25, fol. 81] is emphasized with capital $P$ in cinnabar in the beginning of the line and can be perceived as a subtitle, closely related to the general title. According to G. M. Barats, it is only a variant of Russkaya Pravda title; N. A. Maksimeyko believed it to be an opposition between Kievskaya (of Yaroslavichi) and Novgorodskaya (of Yaroslav) Pravda [12]. It is critical to mention, that though both titles contain the word pravda, these are the only occurances of this word in the whole text of the Short Pravda. Here it means 'law, judicial regulation', i.e. it serves as the title of a regulatory act; this meaning is supported with the verb forms ustavlena, ustavilb (Izyaslavb) of istaviti - 'to formalize, to resolve' [23]: pravda stands for law principles and rules of procedure, set by princely power. According to M. B. Sverdlov, this edition of Russkaya Pravda had the heading Sud Yaroslavlb Volodimeričb [26], which was omitted by the chronicler; if that is so, then pravda expresses the same meaning as that in the title of the Extensive edition from Merilo Pravednoye as the authors have mentioned before.

Besides, the word pravda in the title of the text in the annual entry has meaningful relations with the words in the preceding context of the chronicle: pravda, ustavb, gramota (see Table 2).

The noun pravda in the annual entry has the meaning 'order, rule, law' like ustavb [8], while the phrase dati pravdu is synonymous to the verb ustaviti. The quotation stresses the fact of writing the statute and formalizing it in a document charter - which evokes an additional component in the semantics of the word pravda: law principles (pravda) can exist in oral form while here they are presented as written. The authors are not touching upon the question whether Russkaya Pravda was actually granted by Yaroslav or it was another charter [10], [18], [27], [28], [29]; by describing the semantics of the word Pravda, the authors rely on its actual usage in context in this fragment of the chronicle. However, it should be noted that the compositional principles of Russkaya Pravda differ from most Old Russian statutory and other charters which, as a rule, begin with the phrase «Se $a z b$ (name)» and end with the so-called 'protective' lines [30], [31]. Although it is not a traditional charter in its classical form, it is regarded as an official written document.

The text of the chronicle in the manuscript is followed by a series of legal texts [25, fol. 265-305 v.], including Russkaya Pravda. These are Pravilo zakonbno o cerkovnyih lyuděh..., $O$ mérilěhs, Pravilo svyatyh otecb 165 5-go sobora..., Rukopisanie svyatogo knyazya krestivъšago Ruskuyu zemblyu, Ustavъ Yaroslavlb, sudy svyatitelbskya, O ženitvě, Ustavъ velikogo knyazya Vsevoloda o cerkovnyhb suděhъ, $i$ o lyuděhı, i o měrilahs torgovyh, Ustav velikogo knyazya Yaroslava, Ustav Volodimerb Vsevolodičya, Ustavb Yaroslava knyazya o mostěhs, Rukopisanie knyazya Vsevoloda. It also features the Extensive edition of Pravda, in which the Statute of Vladimir Vsevolodovich is included as a separate text with its own title.

Let us examine the text of Pravda placed in the 'supplement' to the chronicle which represents a collection of laws; it is listed under the title Ustav velikogo knyazya Yaroslava (written in ligatures with cinnabar ink). The text begins with an excerpt from Slovo Vasiliya Velikogo o sudbyah i klevetah (Word of St. Basil the Great on judges and slander), and then is followed by the text titled Pravbda

TABLE II THE WORD PRAVbDA IN NOVGOROD FIRST CHRONICLE (ANNUAL ENTRY)

\begin{tabular}{|c|c|c|c|}
\hline \multicolumn{4}{|c|}{$\begin{array}{l}\text { Novgorod First Chronicle of Younger Recension according to the } \\
\text { Commission List, } 15^{\text {th }} \text { cent. } \\
\text { (annual entry) }\end{array}$} \\
\hline $\begin{array}{l}\text { pravda } \\
\text { crules of } \\
\text { court, law' }\end{array}$ & $\begin{array}{l}\text { ustavb (spisavb) } \\
\text { 'law, legislative } \\
\text { document' }\end{array}$ & $\begin{array}{l}\text { gramota } \\
\text { 'document } \\
\text { charter' }\end{array}$ & $\begin{array}{c}\text { pravda } \\
\text { rusbskaya } \\
\text { 'rules of court, } \\
\text { law' } \\
\text { Pravda } \\
\text { ustavlena } \\
\text { 'rules of court, } \\
\text { law' } \\
\text { ustavilb }\end{array}$ \\
\hline
\end{tabular}


rusbskaya, written in lower case [12], which provides for its perception as a subtitle. The title Ustav Volodimerb Vsevolodicya is also written in ligatures with cinnabar ink. The chapters of Zakon Sudnyi Lyudem, attached to the Ustav (which, however, are not divided graphically in the manuscripth), are believed by some scholars to be included by mistake [12].

In this copy of Russkaya Pravda the lexeme pravda is used in the title (subtitle) and in articles 21, 56, 85 (similar to the copy of Merilo Pravednoye). It relates to the word ustavb and bears the meaning of 'ordeal', 'judgment, trial' (in the articles), and 'law, judgment and proceedings statute' (in the subtitle) (see Table 3).

The word pravbda semantically relates to the words that are used in the titles of other legal texts - ustavb, pravilo, pravilo zakonbno, rukopisanie - 'command, order, or instruction, confirmed in writing' [8] and with the word suds in these titles, which determines its understanding as 'court acts'. Among these terms of key importance the word ustavb is defined as 'name of the document, regulating a specific social subject'; it affects the meaning of the phrase Pravda Rusbskaya as the name of the document which is essentially ustav (statute). Considering the secular context of the book, the term pravda is generally used in its legal secular aspect.

The word mérilo (gradskoye, torgovoye) is also used in common meaning of 'scales, an instrument for measuring something'.

TABLE III. THE WORD PRAVBDA IN NOVGOROD FIRST CHRONICLE (COLLECTION)

\begin{tabular}{|c|c|c|c|}
\hline \multicolumn{4}{|c|}{$\begin{array}{l}\text { Novgorod First Chronicle of Younger Recension according to the } \\
\text { Commission List, } 15^{\text {th }} \text { cent. } \\
\text { (collection) }\end{array}$} \\
\hline $\begin{array}{l}\text { PRAVILO } \\
\text { ZAKONb- } \\
\text { NO } \\
\text { RUKOPI- } \\
\text { SANIE } \\
\text { USTAVЪ } \\
\text { SUDY } \\
\text { USTAVЪ } \\
\text { O } \\
\text { SUDĚHЪ } \\
\text { USTAVЪ }\end{array}$ & $\begin{array}{l}\text { USTAVT } \\
\text { sudb } \\
\text { sudb božii } \\
\text { suditi } \\
\text { sudiya } \\
\text { zakonb } \\
\text { zakonz božii } \\
\text { uzakoniti } \\
\text { zapovědi } \\
\text { pravda 'truth, } \\
\text { justice' } \\
\text { pravyi 'innocent' } \\
\text { pravednyi } \\
\text { 'honest' } \\
\text { opravdati 'acquit' } \\
\text { ispraviti 'correct' } \\
\text { Pravda } \\
\text { rusbskaya } \\
\text { 'rules of court, } \\
\text { law' } \\
\text { sudilı } \\
\text { ustaviša } \\
\text { pravda 'trial } \\
\text { ordeal' }\end{array}$ & $\begin{array}{l}\text { USTAVЪ } \\
\text { ustavb } \\
\text { ustaviti } \\
\text { suditi } \\
\text { pravda } \\
\text { 'judgment, } \\
\text { trial' } \\
\text { pravda } \\
\text { 'judgment, } \\
\text { trial' } \\
\text { sudomb } \\
\text { suditi } \\
\text { sudebnyi } \\
\text { zakonb } \\
\text { zakonb božii } \\
\text { uzakoniti } \\
\text { zapovědi } \\
\text { sudb } \\
\text { sudb božii } \\
\text { sudiya } \\
\text { osuditi } \\
\text { pravdivъ } \\
\text { 'innocent' } \\
\text { opravdati } \\
\text { 'acquit' } \\
\text { pravednyi } \\
\text { 'honest, just' } \\
\text { pravb 'just' }\end{array}$ & $\begin{array}{l}\text { USTAVЪ } \\
\text { RUKOPISANIE }\end{array}$ \\
\hline
\end{tabular}

However, the preamble, i.e. the moral 'Word of St. Basil the Great on judges and slander' (which is included in the first part of Merilo Pravednoye in Extended version [22, fol. 20 v.21 v.]) and chapters from Zakon Sudnyi Lyudem expand the semantics of the word pravda. This is supported with frequent occurences of the words sudb, suditi, osuditi, sudiya, zakons, uzakoniti, bezakonnyi, zapovédb in phrases like sud božii [25, fol. 296 v.], božii zakons and zakonb lyudskyi [25, fol. 292], božiya zapovědi prestuplenie [25, fol. 296]. The perception of court and law is augmented with moral and spiritual component, enriching the notion of pravda in the same manner.

The Word of St. Basil the Great and Zakon Sudnyi Lyudem contain frequent derivates with the root -prav- as in pravda, pravyi, pravednyi, pravdivb, opravdati, opravditi, ispraviti. They represent abstract concepts of 'truth, fairness', 'innocent', 'fair', 'righteous', 'to determine innocence' among others, thus forming the semantic subset of 'court, law and fairness' composed of the derivatives with the roots sud-, zakon-. In some fragments these lexemes are found in close proximity, sometimes within one sentence, where they semantically interweave, e.g. «gore opravdayuščemu nečestivago mbzdy radi i ot pravago pravdu otbyemlyuščemu. Davyi bo namъ bogr vlastb istyažetb skoro vaša déla i pomysli ispytaetb; yakože bo služitele este carstviya, ti ne sudiste pravo, ni šhraniste zakona božiya [25, fol. 279]; «Ašče li ne pravb sud, to vъzidutb kb velikomu otmestniky, egože postavi vlastb naša pomagati sirotě $i$ vdovicě vъ pravdu, rekšu bogu $i$ prorokomb: sudite sirotě $i$ opravdaite vdovicyu; to $d a$ ispravitb velikii sudiya, $i$ obidyai sirotu da priimetb sud protivu délomb» [25, fol. 301], etc. Patterns of meaning that are found in these contexts express an appeal to the supreme power and supreme court, claiming that the truth is no longer the princely court, but the justice of God and God's fairness.

The idea of fairness of court as embodiment of God's truth that is, as the authors have shown above, represents the axis of Merilo Pravednoye and other books of a similar nature. In the annual entry the lexeme pravda is used to report about historical events and the contents of the document are directly related to the events described. However, beyond this narrative, in contextual surrounding of legal texts of Russian and foreign origin that are included in the book for purposes different from the one that is characteristic of the manuscript in question, this lexeme acquires additional meanings. It appears that even in the mind of a $15^{\text {th }}$ century scribe, the writer of the chronicle, the lexeme pravda already had developed regular connotations, and Russkaya Pravda was thought of in relation to other texts (though it was probably not used as practice guideline), which is why it was chosen to introduce a spiritual and moral preamble, taking a fragment from the work of St. Basil the Great.

\section{CONCLUSION}

To conclude, interpretation of the famous Old Russian manuscript on justice Russkaya Pravda is determined by a series of reasons. Considering semantic syncretism as a peculiar feature of an ancient word, it is necessary to avoid oversimplification when giving meaningful definition to the lexeme pravda, which simultaneously means 'fairness', 
'truth', 'rightness (innocence)', and 'an action directed at establishment of the truth which is implemented in accordance with the truth (God's truth), and the law governing such actions'. The complexity of the term pravda manifests itself in the titles of the legal manuscripts analyzed. Although it essentially bears a terminological meaning throughout the document, in effect, through numerous associations that are conditioned by lexical and derivational relations with other Old Russian words and in the context of culturally significant texts this word meaning provides insights not only into historical circumstances of the epoch but also the axiological universe of the Old Russian mentality.

\section{Acknowledgment}

The authors express their gratitude to Doctor of Economy, Professor Oleg Vasil'evich Inshakov who inspired this study; the authors are also grateful to Doctor of Philology, Professor Elena Y. Ilyinova, Doctor of Philology, Associate Professor Larisa A. Kochetova, post-graduate student of the English chair of Volgograd University V. Voskoboinikov for invaluable help and assistance in preparation of this study for publication.

\section{References}

[1] M. Fasmer, Etymological Dictionary of the Russian Language, Moscow : Progress, 1986-1987 (in Russian).

[2] A.M. Selishchev, The Old-Slavonic Language, Moscow : Editorial URSS, 2001. (in Russian).

[3] A. Meye, Common Slavic Language, Moscow : Progress, 2001. (in Russian).

[4] R.M. Tseytlin, Comparative Lexicology of the Slavonic Languages 5/11th-14/15th Centuries. Problems and Methods, Moscow : Nauka, 1996. (in Russian).

[5] Etymological Dictionary of Slavic Languages: Proto-Slavic Lexical Fund, O.N.Trubachev, A.F.Zhuravlev, Eds. Moscow : Nauka, 19742014. (in Russian).

[6] Old Church Slavonic Dictionary (Based on the Manuscripts of the 10th11th Centuries), Tseytlin R.M., Vecherka R., Blagova E., Eds. Moscow : Russkiy yazyk, 1994. (in Russian).

[7] Dictionary of Old-Russian Language of 11th-14th Centuries, Moscow : Russkiy yazyk; Azbukovnik, 1988-2016. (in Russian).

[8] Dictionary of Russian Language of 11th -17th Centuries, Moscow : Nauka, 1975-2015. (in Russian).

[9] Certificate Granted to Vasiliy Mikhaylovich and Appanage Tver Princes Vsevolod Aleksandrovich, Mikhail Aleksandrovich, Vladimir Aleksandrovich, Andrey Aleksandrovich and others on Exemption of People from Tver Otroch Monastery from Tribute and Customs. (in Russian).

[10] S.V. Yushkov, Russkaya Pravda. The Origin, Sources, and Its Value, Moscow : Zertsalo, 2010. (in Russian).

[11] M.V. Korogodina, "On the Composition of the Merilo Pravednoye", in Historiography and Source Studies of Russian History. Collected Papers. Historical Narrativein Medieval Russia. To the 450th Anniversary of the Stepennaya kniga, Moscow; Saint Petersburg : KRISMAS+, 2014, pp. 94-112. (in Russian).
[12] Pravda Russkaya, B. D. Grekov, Ed. Moscow; Leningrad : AN SSSR, 1940, 1947. (in Russian).

[13] V.V. Kolesov, The Old-Russian Civilization. The Legacy in the Word, Moscow : Institut russkoy tsivilizacii, 2014. (in Russian).

[14] O.A. Cherepanova, "On the Correlation between the Concepts of "Semantic Syncretism" and "Lexico-Semantic Group" Applied to the Lexical System of the Old Russian Language", Russian Culture of the New Century. Problems of Study, Preservation and Use of Historical and Cultural Heritage, Vologda : Knizhnoe nasledie, 2007, pp. 692-697. (in Russian).

[15] M.V. Pimenova, Decorate with Beauty: Expression of Aesthetic Evaluation in the Ancient Text, Saint Petersburg : Filologicheskiy fakultet SPbGU; Vladimir : VGU, 2007. (in Russian).

[16] N.V. Krushevskiy, Spells as a Form of Russian Folk Poetry, Selected Works on Linguistics, F.M. Berezin and V.N. Yartseva, Eds. Moscow : Nasledie, 1998, pp. 96-222. (in Russian).

[17] V.V. Kolesov, Semantic Syncretism as a Language Category, Vestnik Leningradskogo universiteta. Seriya 2, Istoriya, yazykoznanie, literaturovedenie, is. 2, No. 9, 1991, pp. 40-49. (in Russian).

[18] A.A. Zimin, Russkaya Pravda, Moscow, Drevlekhranilishche Publ., 1999. (in Russian).

[19] A.A. Gippius Russkaya Pravda and Voproshanie Kirika (The Questions of Kirik) in the Novgorod Kormchaya 1282 (Linguistic Situation of Ancient Novgorod), Slavyanovedenie, 1996, no. 1, pp. 48-62. (in Russian).

[20] G.A. Nikolaev, The Functional Aspect of the Historical Word Formation, Sentence and Word, Saratov : Nauka, 2008, pp. 451-458. (in Russian).

[21] O.M. Shukova, The Peculiarities of Implementing the Categories of Text in the "Izbornik 1076 goda, in Vestnik Pomorskogo universiteta, No. 5, 2008, pp. 135-138. (in Russian).

[22] Merilo pravednoe, $14^{\text {th }}$, Moscow : AN SSSR, 1961. (in Russian).

[23] I.I. Sreznevskiy, Materials for Dictionary of the Old Russian Language according to Manuscripts, Moscow : Znak, 2003. (in Russian).

[24] N.S. Kovalev, The Old Russian Literary Text: Problems of Studying Semantic Structure and Evolution in the Aspect of Assessment Category, Volgograd : Izd-vo VolGU, 1997. (in Russian).

[25] Novgorod First Chronicle of Older and Younger Recensions, Complete Collection of Russian Chronicles, Moscow : Yazyki russkoy kultury, vol. III, 2000, pp. 101-427, 465-509. (in Russian).

[26] M.B. Sverdlov, From the Russian Law to Russkaya Pravda, Moscow : Yurid. lit., 1988. (in Russian).

[27] Shakhmatov A.A. Research on Russian Chronicles,Moscow : Akademicheskiy proekt; Zhukovskiy : Kuchkovo pole, 2001. (in Russian).

[28] M.N. Tikhomirov, A Study of Russkaya Pravda: the Origin of Texts, Moscow ; Leningrad : AN SSSR, 1941. (in Russian).

[29] Georgievskiy E.V. "On the General Characteristics and Origins of Russkaya Pravda", Sibirskiy yuridicheskiy vestnik, No. 1 (44), 2009, pp. 74-81. (in Russian).

[30] S.P. Lopushanskaya, Linguistic Description of the "Ustav Sviatoslava Olgovicha"], Problems of Historical Linguistics. The Literary Language of Ancient Rus, Leningrad : Izd-vo LGU, 1986, pp. 131-137. (in Russian).

[31] Gorban O.A. The Expression of Temporality in the Old Russian Charters' Texts, Kryuchek V.K., ed. Current Problems of Social Sciences and Creative Professions (Philosophy, History, Sociology, Culture, Art, Religion), Volgograd, Volgogradskoe nauchnoe izd-vo, 2010, vol. 5, pp. 19-30. (in Russian) 